\title{
Diagnosis, recommendations and optimization for potable water treatment plant in Cauca (Colombia)
}

\author{
Dustin Stephan Melendez Giraldo \\ Peoples' Friendship University of Russia (RUDN University), 6 Miklukho-Maklaya St., Moscow, 117198, Russian Federation
}

Article history:

Received: October 21, 2019

Revised: November 27, 2019

Accepted: November 29, 2019

\section{Keywords:}

water supply, water treatment, physical, chemical and microbiological test, coagulation, flocculation, sedimentation, filtration, optimization
Currently the water supply system in the municipality of Corinto (Cauca) in Colombia provides drinking water to the entire urban and rural population of the municipality. In order to provide drinking water to the entire population, it became necessary to optimize and/or expand the existing water treatment plant. The article presents an assessment of the consideration of two optimization options: the need for reconstruction of existing water treatment facilities or the construction of additional water treatment units. A reasonable proposal was made to expand the station by building additional water treatment units, including advanced modern water treatment technologies, such as coagulation, flocculation, sedimentation, filtration, sorption, settling using thin-layer modules and disinfection, based on the survey (diagnostics), technical and economic analysis, analysis of the efficiency of the existing water treatment plant, taking into account the quality of drinking water preparation, confirmed by the analysis of samples, the results of physical, chemical and microbiological tests, indicating the optimal quality of drinking water for human consumption. The use of modern water treatment technologies will allow to achieve the required quality of purified sufficient water for drinking purpose.

\section{Introduction}

In the municipality of Corinto (Cauca) in Colombia, it became necessary to implement alternatives to improve water for human consumption, to develop different operations and processes that allow the purification of raw water, ensuring priority welfare of the population, all this in order to reduce the spread of diseases transmitted by untreated water.

Dustin Stephan Melendez, Giraldo, civil engineer, master student of Department of Civil Engineering of Academy of Engineering of RUDN University; 1032175857@, rudn.ru; ORCID iD: https://orcid.org/0000-0003-3592-3457. (C) Melendez Giraldo D.S., 2019

This work is licensed under a Creative Commons Attribution 4.0 International License

https://creativecommons.org/licenses/by/4.0/
The focus of this document is to design several optimizations for Corinto municipality potable water treatment plant in Cauca, Colombia through the diagnosis of the processes and operations carried out in the plant and optimization alternatives $[1 ; 2]$. Using either the current hydraulic configuration of units or designing new units as a basis for the improvement of the old one, to increase the coverage of treated water for the future generations [3].

The PWTP current units design will be completing in 2020, therefore, it is necessary to conduct a study of current state and to generate an optimal alternative to increase the facilities of hydraulic capacity. 


\section{Methodology}

Diagnosis. To execute the proposal, it is necessary to make a diagnosis of the PWTP current state, characterizing the catchment points, and identifying the treatment operations, by verify that the design parameters of each process are between the ranges established by the RAS2000 - Title C (Colombia's regulation) and determine the physical-chemical and microbiological characteristics of the treated water [4].

This would allow to recommend the best alternative for the Corinto's PWTP optimization. Below are the activities that were developed in the diagnosis:

- Activity 1: PWTP exploration.

- Activity 2: Technical information analysis.

- Activity 3: Check design parameters of the treatment processes.

- Activity 4: Samples collection.

- Activity 5: Physical-chemical and microbiological water parameters tests.

The purpose of each activity:

Activity 1 , to identify the treatment units, and report about operation and construction materials.

Activity 2, a detailed analysis of each treatment process that was carried out in the PWTP, with the dimensions of the units, which were the product of measurements made in the first activity and a plan provided by EMCORINTO E.S.P.

Activity 3 , to verify the design parameters of each existing treatment process (rapid mix, slow mix, sedimentation and filtration) among the ranges established by the RAS 2000 - Title C.

Activity 4, to explain the method used to collect water samples.

Activity 5, to show the physical-chemical and microbiological parameters of raw, sedimented and treated water.

Optimization alternative. At the end of the PWTP diagnosis, an alternative to be developed for the plant optimization, however before, it should be verified which units could work, with the designed flow rate.

The activities that developed in this stage are as following:

- Activity 6: Identify the critical points in the existing treatment units.

- Activity 7: Verify the hydraulic capacity of the current PWTP designs.

- Activity 8: Elaboration of the design alternative.

In summary, what has done in each activity:

Activity 6 , the different problems in the diagnosis should be identified, emphasizing each one of them and what consequences they could cause to the water treatment.

Activity 7, with the required flow designed for the rural and urban population, should be proceeded to verify that the operation of the units is optimal for the treatment.

Activity 8, the design alternative should be presented for the units that cannot treat the designed flow.

Designing of alternative budget and general recommendations. Once the design alternative was chosen, an approximate budget of the changes and additions proposed in the design alternative should be done, and recommendations for the optimization of the PWTP also should be developed.

\section{Procedure and results analysis}

Diagnosis. The Corinto's aqueduct system has two bottom water intakes, one intake on La Paila river and another one on El Chicharronal stream, as well as four grit chamber tanks, three on La Paila catchment and one on El Chicharronal catchment. After the water is captured by this system, it is conducted to the PWTP, which is of a conventional type. It is also composed of an arrival chamber, gauging station, rapid mixing (rectangular spillway), horizontal hydraulic flocculator, conventional sedimentation tank with parallel plates, rapid sand filter, chlorine dosing. Finally, the water is stored in three tanks, the first one with a storage capacity of $600 \mathrm{~m}^{3}$, the second one with the capacity of $800 \mathrm{~m}^{3}$ (both tanks half-buried) and the last one is an elevated tank with the capacity of $10 \mathrm{~m}^{3}$.

The PWTP treatment process is shown in Figure 1.

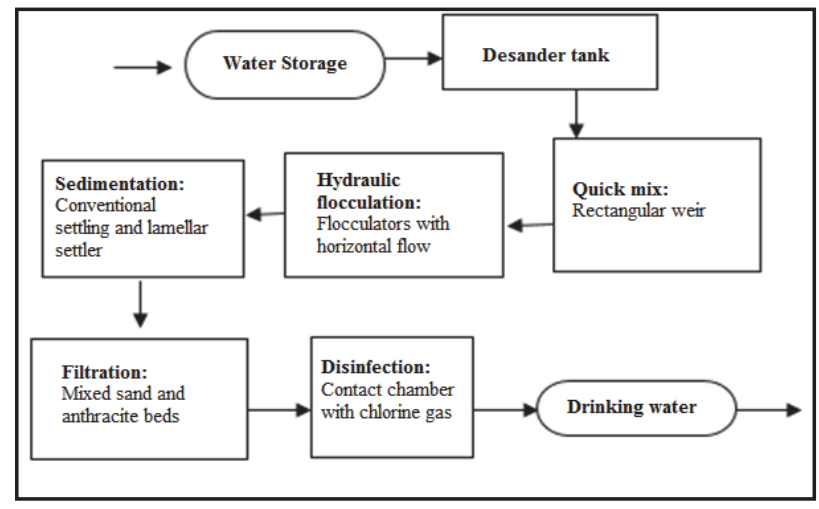

Figure 1. Plant processes treatment

After the current dimensions registion by EMCORINTO E.S.P., the PWTP hydraulic behavior was calculated. 


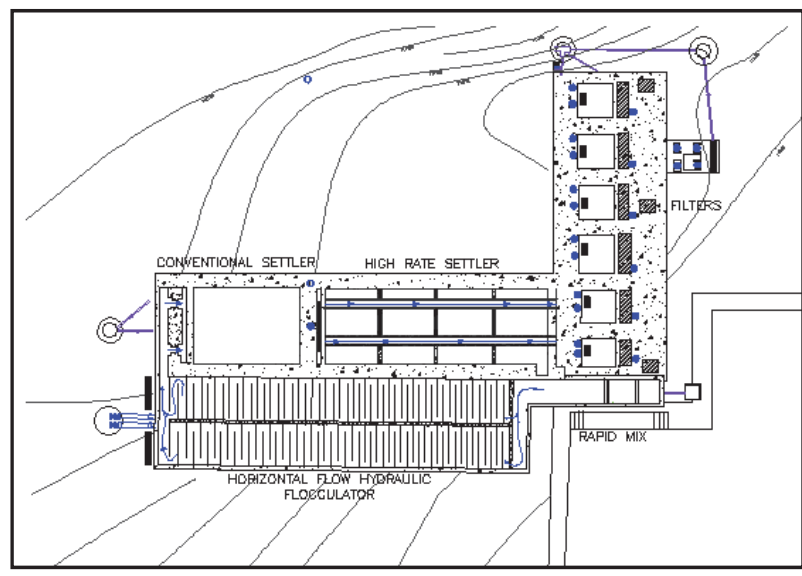

Figure 2. Existing treatment plant

The results on the design parameters of each process were the following.

Rapid mixing: analysis shows that the turbulence generated by the hydraulic shoulder is sufficient to produce an intermix between aluminum sulphate solution and water mass, since its hydraulic gradient is between the range of 1000 and $3000 \mathrm{~s}^{-1}[5 ; 6]$.

Slow mixing: the flocculation tanks are composed of horizontal screens, in these three different speeds for each unit were obtained, which is very common in flocculators divided by different gradients - the objective is to start the canal path with a high speed, but not higher than $0.60 \mathrm{~m} / \mathrm{s}$ and finish with a low speed, but not lower than $0.10 \mathrm{~m} / \mathrm{s}$.

Sedimentation: the surface charge conventional settler is too high ( $294 \mathrm{~m} /$ day), this is due to the lack of surface area, for this reason the speed $v$ resulting between the sedimentation theoretical decomposition velocity $v_{o}$ and the horizontal drag velocity produced by the fluid $v_{f}$ will be very high and some particles will not reach sedimentation [7-9].

Filtration: in relation to the filtration process, it was obtained that the entire battery works with a surface load of $333 \mathrm{~m} /$ day, besides, its filtration capacity is high, and its filtering medium is mixed its works with anthracite and sand.

Regarding the physical-chemical and microbiological tests, the plant demonstrated to deliver the municipality with water of excellent quality, since it meets all the parameters required by Resolution 2115 of 2007 (Colombian regulation).

It is clearly seen that the water at the exit of the filters is already suitable for human consumption.

Then the design flow rate is determined with the calculated population, as well as the hydraulic parameters of the units, to verify that these can treat the required flow rate for the future population.
Water analysis

\begin{tabular}{|c|c|c|c|c|c|}
\hline Sample & $\begin{array}{l}\text { Turbidity } \\
\text { (NTU) }\end{array}$ & $\mathrm{pH}$ & $\begin{array}{l}\text { Color } \\
\text { (UPC) }\end{array}$ & $\begin{array}{l}\text { Tempe- } \\
\text { rature } \\
\left.\text { ( }{ }^{\circ} \mathrm{C}\right)\end{array}$ & Hour \\
\hline \multirow{3}{*}{ PWTP Entry } & 488 & 7,62 & 190 & 21,9 & $00: 00 \mathrm{~h}$ \\
\hline & 373 & 7,65 & 177 & 21 & $06: 00 \mathrm{~h}$ \\
\hline & 274 & 7,6 & 127 & 23,7 & $12: 00 \mathrm{~h}$ \\
\hline \multirow{3}{*}{$\begin{array}{l}\text { Outlet of } \\
\text { the conven- } \\
\text { tional settler }\end{array}$} & 44,7 & - & - & - & $00: 00 \mathrm{~h}$ \\
\hline & 37,7 & - & - & - & $06: 00 \mathrm{~h}$ \\
\hline & 33,9 & - & - & - & $12: 00 \mathrm{~h}$ \\
\hline \multirow{3}{*}{$\begin{array}{c}\text { Outlet of } \\
\text { the lamellar } \\
\text { settler }\end{array}$} & 8,12 & 6,89 & 4 & 20,6 & $00: 00 \mathrm{~h}$ \\
\hline & 8,69 & 6,91 & 4 & 20,3 & 06:00 h \\
\hline & 10,3 & 6,8 & 5 & 22,7 & $12: 00 \mathrm{~h}$ \\
\hline \multirow{3}{*}{$\begin{array}{l}\text { Output of } \\
\text { the filters }\end{array}$} & 0,96 & 6,8 & 0 & 20,9 & $00: 00 \mathrm{~h}$ \\
\hline & 1,07 & 6,83 & 0 & 20,4 & 06:00 h \\
\hline & 1,15 & 6,79 & 0 & 22,6 & $12: 00 \mathrm{~h}$ \\
\hline
\end{tabular}

Table 2

Population projection, design flow rate

\begin{tabular}{|c|c|c|c|c|c|c|}
\hline Year & $\begin{array}{l}\text { Popu- } \\
\text { lation }\end{array}$ & $\begin{array}{c}\text { Net } \\
\text { endow- } \\
\text { ment } \\
\text { (L/Hab/ } \\
\text { day) }\end{array}$ & $\begin{array}{c}\text { Gross } \\
\text { endow- } \\
\text { ment } \\
\text { (L/Hab/ } \\
\text { day) }\end{array}$ & $\begin{array}{l}\text { Ave- } \\
\text { rage } \\
\text { daily } \\
\text { flow } \\
\text { rate } \\
\text { (L/s) }\end{array}$ & $\begin{array}{l}\text { Maximum } \\
\text { daily flow } \\
\text { rate (L/s) }\end{array}$ & $\begin{array}{c}\text { Design } \\
\text { flow } \\
\text { rate } \\
\text { (L/s) }\end{array}$ \\
\hline 2019 & 27170 & 125 & 167 & 52 & 63 & 64 \\
\hline 2024 & 28956 & 125 & 167 & 56 & 67 & 69 \\
\hline 2029 & 30905 & 125 & 167 & 60 & 72 & 73 \\
\hline 2034 & 33052 & 125 & 167 & 64 & 77 & 78 \\
\hline 2039 & 35451 & 125 & 167 & 68 & 82 & 84 \\
\hline 2044 & 38179 & 125 & 167 & 74 & 88 & 91 \\
\hline
\end{tabular}

Table 3

Hydraulic capacity for design flow rate $(91 \mathrm{~L} / \mathrm{s})$

\begin{tabular}{|c|c|c|c|c|}
\hline \multicolumn{5}{|c|}{ Rapid mixing: Thin-walled rectangular weir } \\
\hline Parameters & Rank & Result & Fulfill & Fail \\
\hline $\begin{array}{l}\text { Froude } \\
\text { number }\end{array}$ & $4,0-9,0$ & 4,055 & $\mathrm{X}$ & \\
\hline Mix time & $<1 \mathrm{~s}$ & $0,675 \mathrm{~s}$ & $\mathrm{x}$ & \\
\hline $\begin{array}{l}\text { Velocity } \\
\text { gradient }\end{array}$ & $1000 s^{-1}-2000 s^{-1}$ & $1482 \mathrm{~s}^{-1}$ & $\mathrm{X}$ & \\
\hline \multicolumn{5}{|c|}{ Slow mixing: Flocculator } \\
\hline Mix time & $10-15 \min$ & 8,46 & & $\mathrm{x}$ \\
\hline \multicolumn{5}{|c|}{ Sedimentation: Lamellar settler } \\
\hline $\begin{array}{l}\text { Surface } \\
\text { charge }\end{array}$ & $120-300 \mathrm{~m}^{3} / \mathrm{m}^{2} /$ day & $\begin{array}{c}240 \\
\mathrm{~m} / \text { day }\end{array}$ & $\mathrm{X}$ & \\
\hline \multicolumn{5}{|c|}{ Filtration: High rate filters } \\
\hline $\begin{array}{l}\text { Surface } \\
\text { charge }\end{array}$ & $235-350 \mathrm{~m}^{3} / \mathrm{m}^{2} /$ day & $\begin{array}{l}550 \\
\mathrm{~m} / \text { day }\end{array}$ & & $\mathrm{X}$ \\
\hline
\end{tabular}




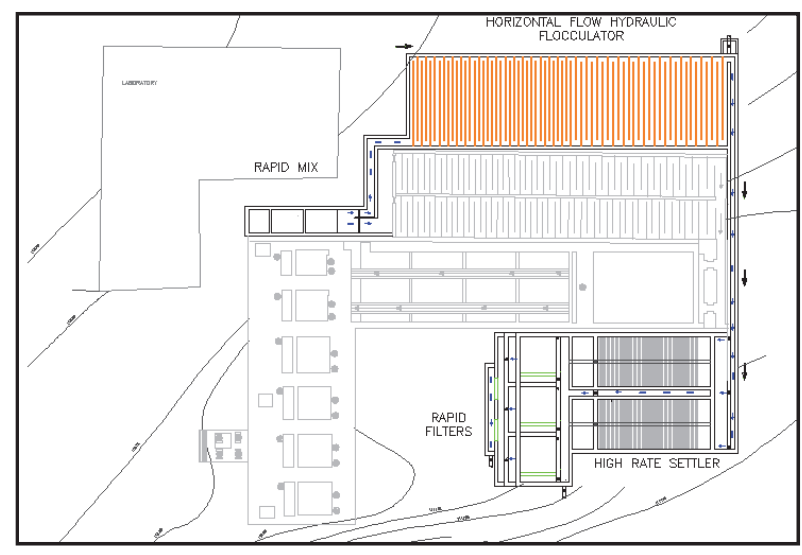

Figure 3. Projected treatment plant

In accordance with the previous points, it is necessary to design new units for the flow that cannot treat existing units, in addition the PWTP in general is working well and it would not be appropriate to alter its operation by modifying the existing units, so the following alternative was proposed (Figure 3 ).

Flocculation: The option of mechanical flocculators was not considered enough due to the low usual source turbidity and the high cost owing to the electrical energy they need for their operation. On the other hand, there are no topographical restrictions that do not allow a new flocculator structure next to the other two existing units. The previous one chooses by a flocculator hydraulics of horizontal flow, divided in two sections [10-12].

The designed flocculator is rectangular type with $15.22 \mathrm{~m}$ length $\times 4.30 \mathrm{~m}$ width and $1.30 \mathrm{~m}$ depth, guaranteeing a detention period of 21 minutes for a flow of $36 \mathrm{l} / \mathrm{s}$. The total flocculation time is $21 \mathrm{mi}-$ nutes - therefore, each section will retain the flow for 10.5 minutes.

Sedimentation: A high rate settler with laminar flow rate was adopted, with a decanter composed of two compartments, each with $2.40 \mathrm{~m}$ width $\times 5.40 \mathrm{~m}$ length and $4.26 \mathrm{~m}$ depth.

The compartments are separated by a rectangular canal of $0.30 \mathrm{~m}$ width $\times 0.25 \mathrm{~m}$ height.

The zone of plates of the settler has a length of $5.40 \mathrm{~m}$, formed by fibrocement plates of $2.40 \mathrm{~m} \times$ $1.20 \mathrm{~m}$ and $8 \mathrm{~mm}$ thickness, inclined at $60^{\circ}$ with respect to the horizontal, in addition to free spacing of $5 \mathrm{~cm}$.

Filtration: It is a high rate system filtration, with sand and anthracite double filtering media. The cleaning of the filters is done by self-cleaning.

The filter battery is composed of 3 filters with compartment of $1.75 \mathrm{~m}$ width, $1.70 \mathrm{~m}$ length and
$3.65 \mathrm{~m}$ total depth. A net filtration area of $3.0 \mathrm{~m}^{2}$ per unit is available in this form.

The direct costs are approximate according to the catalogs, so once all the designs have been made: hydraulic, structural and foundation, it is recommended to redo the project budget.

Table 4

Approximate direct cost of the design

\begin{tabular}{llc}
\hline 1. & Preliminary works & 918 USD \\
2. & Earth works & 13300 USD \\
3. & Structural works & 35424 USD \\
4. & Installation of pipes and accessories & 2105 USD \\
5. & Sedimentation system & 918 USD \\
6. & Filtration system & 1506 USD \\
7. & Equipment and accessories for flow control & 9358 USD \\
\hline
\end{tabular}

It was determined that the approximate direct cost of the design is 66935.33 USD [13].

\section{Recommendations}

The following alternative is presented since author's point of view like the most optimum one, given the topographical, structural and operational conditions of the project. In this paper a hydraulic and operative optimization of the plant is assumed, it is recommended to adjust the budget, in case of carrying out the proposed improvement alternative, considering structural and foundation designs [14-16].

\section{Conclusion}

The results obtained in the physical-chemical and microbiological tests show that the water quality is optimal for human consumption, at the same time, it justifies that the existing water treatment units can continue to operate under the current conditions.

The alternative, that was developed throughout the project, promises to be the most viable, since its operation will not affect the operation of existing units.

All the processes of drinking water treatment, such as rapid mix, slow mix, sedimentation and filtration, require more research in terms of design and operation, that's why it is necessary to have all the required designs for its optimization.

The budget for the design alternative, does not take into account the costs of structural designs or foundation, so the result is an approximate value. 


\section{References}

1. Valencia JA. Teoria y practica de la purificación del agua. Bogota D.C.: NOMOS S.A.; 2000. vol. I.

2. Valencia JA. Teoria y practica de la purificación del agua. Bogota D.C.: NOMOS S.A.; 2000. vol. II.

3. Villegas de Brigard MP. Purificación de aguas. Bogotá: Segunda; 2007.

4. Ministerio de desarrollo económico, dirección de agua potable y saneamiento basico. Reglamento técnico del sector de agua potable y saneamiento básico RAS - 2000. Sección II. Título C. Sistemas de potabilización. Available from: http://www.minambiente.gov.co/documentos/TituloC.PDF

5. Universidad Nacional Abierta y a Distancia. 2013. Available from: https://es.scribd.com/document/347030348/ MODULO-CURSO-DISENO-DE-PLANTAS-POTABI LIZADORAS-II-2013-pdf

6. Romero JA. Potabilizacion. Diseño De Sistemas De Purificación De Aguas. Tercera edición. Bogotá, Colombia: Escuela Colombiana de Ingeniería; 1999.

7. Canepa de Vargas L. Tratamiento de aguas para el consumo humano: plantas de filtración rápida. Manual III. evaluación de plantas de tecnología apropiada. Available from: http://www. bvsde.paho.org/bvsacd/scan/014991/ 014991-04.pdf

8. Canepa de Vargas L. Tratamiento de aguas para el consumo humano: plantas de filtración rápida. Manual II: evaluación de plantas de tecnología apropiada. Available from: http://www.bvsde.paho.org/bvsatr/fulltext/ tratamiento/m anualI/tomoI/ma1_tomo1_cap3.

9. Bernal SM. Propuesta para el mejoramiento de la planta de tratamiento de agua potable del municipio de Bituima, Cundinamarca. Bogota D.C.: Universidad de la Salle; 2011.

10. Bolivar JH. Diagnostico y Optimizacion de la Planta de Tratamiento de Agua Potable, Municipio Puente Nacional. Bucaramanga: Universidad Indistrial de Santander; 2005 .

11. Clavijo A. Evaluacion de la planta de tratamientode agua potable del municio de Garzón-Huila. Bogota D.C.: Universidad Militar Nueva Granada; 2013.

12. Corinto AM. Plan de Desarrollo del Municipio de Corinto. 2011. Available from: http://www.corinto-cauca. gov.co/apc-aafiles/35333035383764393835343462/Plan de_Desarrollo_2008_UltimaVersion.pdf

13. Sweets constructions catalogs, Product Catalogs for Building Products. Available from: https://sweets. construction.com/QuickLinks/productcatalogs

14. Esp E. Empresa de acueducto alcantarillado y aseo. 2016. Available from: http://www.emcorinto.com. co/html/acueducto.html (accessed: 22 November 2016).

15. Muñoz DM. Estado de la PTAP de Corinto, Cauca. 15 July 2016. (D.S. Giraldo, Entrevistador.)

16. Ministerio de la protección social, ministerio de ambiente, vivienda y desarrollo territorial. Resolución número 2115 de 2007. República de Colombia.

\section{For citation}

Melendez Giraldo DS. Diagnosis, recommendations and optimization for potable water treatment plant in Cauca (Colombia). RUDN Journal of Engineering Researches. 2019;20(4):302-307. http://dx.doi.org/10.22363/2312-81432019-20-4-302-307

Научная статья

\title{
Диагностика, рекомендации и оптимизация станции очистки питьевой воды в Кауке (Колумбия)
}

\author{
Д.С. Мелендес Хиральдо \\ Российский университет дружбы народов, Российская Федеращия, 117198, Москва, ул. Миклухо-Маклая, 6
}

История статьи:

Поступила в редакцию: 21 октября 2019

Доработана: 27 ноября 2019

Принята к публикации: 29 ноября 2019

\section{Ключевые слова:}

очистка воды, физико-химические характеристики, микробиологические характеристики, коагуляция, флокуляция, фильтрация, сорбция, седиментация, акведук, оптимизация
В настоящее время система водоснабжения в муниципалитете Коринто (Каука) в Колумбии обеспечивает питьевой водой полностью городское и часть сельского населения муниципалитета. С целью обеспечения питьевой водой всего населения (городского и сельского) возникла необходимость в оптимизации и/или расширении существующей станции водоподготовки. В статье представлена оценка рассмотрения двух вариантов оптимизации: реконструкции существующего сооружения водоподготовки или строительства дополнительных блоков водоподготовки. На основании проведенного обследования (диагностики), технико-экономического анализа, анализа эффективности работы действующей станции водоподготовки, с учетом качества под-

Дустин Стефан Мелендес Хиральдо, инженер-строитель, магистрант департамент строительства Инженерной академии PУДH; 1032175857@rudn.ru; ORCID iD: https://orcid.org/0000-0003-3592-3457. 
готовки воды питьевого качества, подтверждаемого анализом проб, результатами физико-химических и микробиологических исследований, свидетельствующих об оптимальном качестве питьевой воды для потребления человеком, предложено обоснованное решение о расширении станции путем строительства дополнительных блоков водоподготовки, включающих передовые современные технологии водоподготовки, такие как коагуляция, флокуляция, фильтрация, сорбция, отстаивание с применением тонкослойных модулей и обеззараживание. Применение современных технологий водоподготовки позволит добиться необходимого качества очищенной воды для потребления ее человеком в питьевых целях и в достаточных объемах.

\section{Для цитирования}

Melendez Giraldo D.S. Diagnosis, recommendations and optimization for potable water treatment plant in Cauca (Colombia) (Диагностика, рекомендации и оптимизация станции очистки питьевой воды в Кауке (Колумбия)) // Вестник Российского университета дружбы народов. Серия: Инженерные исследования. 2019. Т. 20. № 4. С. 302-307. http:// dx.doi.org/10.22363/2312-8143-2019-20-4-302-307 